\title{
Identifikasi Pemecahan Masalah Matematis Peserta Didik Berdasarkan Tipe Kepribadian Hippocrates-Galenus dan Gender
}

\author{
Danu Yunizar Pamungkas ${ }^{1}$, Rizki Dwi Siswanto ${ }^{2}$ \\ ${ }^{1,2}$ Pendidikan Matematika, Fakultas Keguruan dan Ilmu Pendidikan, Universitas Muhammadiyah Prof. DR. HAMKA, \\ Jl. Tanah Merdeka No.20 Jakarta Timur, Indonesia \\ rizkidwisiswanto@uhamka.ac.id
}

\begin{abstract}
This study aims to identify students' mathematical problem-solving abilities based on the Hippocrates-Galenus personality typology and gender. The method in this study is descriptive qualitative. Purposive sampling technique was used to select 8 research subjects comprising 2 sanguine subjects, 2 choleric subjects, 2 melancholic subjects, 2 phlegmatic subjects with different genders from each personality. The data collection techniques used were questionnaires, tests, and interviews. The triangulation technique is carried out by comparing the results of the mathematical problem-solving ability test with the results of the interview. The conclusion of this study, overall mathematical problem solving ability, male sanguinis is better than female sanguinis in the aspect of problem understanding, male cholerics were better than female cholerics in the aspect of explaining and checking the correctness of the answers got while for other aspects female cholerics are more both male choleric, male melancholy is better than female melancholy in the aspect of explaining and checking the correctness of the answers got while female melancholy is very good in the aspect of making / compiling mathematical models, female phlegmatic is better than male phlegmatic in aspect demonstrate understanding of the problem and create or compile mathematical models.
\end{abstract}

Keywords: Mathematical Problem-Solving Ability; Gender; Personality Typology Hippocrates-Galenus.

\begin{abstract}
Abstrak
Penelitian ini bertujuan untuk mengidentifikasi kemampuan pemecahan masalah matematis peserta didik berdasarkan tipologi kepribadian Hippocrates-Galenus dan gender. Metode dalam penelitian ini adalah deskriptif kualitatif. Teknik Purposive Sampling digunakan untuk memilih 8 subjek penelitian yang terdiri dari 2 subjek sanguinis, 2 subjek koleris, 2 subjek melankolis, 2 subjek plegmatis dengan gender yang berbeda dari masing-masing kepribadian. Teknik pengumpulan data yang digunakan yaitu angket, tes, dan wawancara. Teknik triangulasi yang dilakukan dengan membandingkan hasil tes kemampuan pemecahan masalah matematis dengan hasil wawancara. Kesimpulan penelitian ini, sanguinis laki-laki lebih baik dari sanguinis perempuan dalam aspek pemahaman masalah, koleris lakilaki dapat lebih baik dibandingkan koleris perempuan mengenai aspek menjelaskan dan memeriksa kebenaran jawaban yang diperoleh sedangkan untuk aspek lain koleris perempuan lebih baik daripada koleris laki-laki, melankolis laki-laki lebih baik dari melankolis perempuan dalam aspek menjelaskan dan memeriksa kebenaran jawaban yang diperoleh sedangkan melankolis perempuan sangat baik dalam aspek membuat/menyusun model matematika, plegmatis perempuan lebih baik dari plegmatis laki-laki dalam aspek menunjukkan pemahaman masalah dan membuat atau menyusun model matematika.
\end{abstract}

Kata kunci: Kemampuan Pemecahan Masalah Matematis, Gender, Tipologi Kepribadian Hippocrates-Galenus

Copyright (c) 2021 Danu Yunizar Pamungkas, Rizki Dwi Siswanto

$\square$ Corresponding author: Rizki Dwi Siswanto

Email Address: rizkidwisiswanto@uhamka.ac.id (Jl. Tanah Merdeka No.20 Jakarta Timur, Indonesia)

Received 30 June 2021, Accepted 10 July 2021, Published 04 August 2021

\section{PENDAHULUAN}

Dalam kehidupan sehari-hari muncul berbagai masalah yang dialami oleh manusia, baik itu masalah ekonomi, sosial, dan sebagainya. Masalah-masalah ini harus dipecahkan dengan solusi terbaik agar tidak memunculkan masalah baru nantinya. Seperti halnya masalah yang terjadi dalam kehidupan sehari-hari, pada pembelajaran matematika juga sering dijumpai masalah-masalah yang harus dipecahkan dan juga selesaikan. Ruseffendi (Islamiah et al., 2018) menyatakan, kemampuan pemecahan masalah merupakan bagian penting dalam pembelajaran matematika, bukan hanya bagi mereka yang mempelajari matematika, melainkan juga untuk mereka yang akan menerapkannya dalam kehidupan sehari-hari maupun bidang studi 
Identifikasi Pemecahan Masalah Matematis Peserta Didik Berdasarkan Tipe Kepribadian Hippocrates-Galenus dan Gender,

yang lain. Sabandar (Islamiah et al., 2018) mengemukakan bahwa kemampuan pemecahan masalah matematis merupakan suatu kemampuan yang harus dicapai dan peningkatan kemampuan berpikir matematis merupakan prioritas dalam pembelajaran matematika. Dalam National Council of Teachers of Mathematics (Nuraeni, R., \& Luritawaty, 2016) standar proses pembelajaran matematika terdiri dari pemecahan masalah (problem solving) penalaran dan pembuktian (reasoning and proof), komunikasi matematis (communication), keterkaitan dalam matematika (connection), dan representasi (representation). Peserta didik dituntut untuk menguasai kecakapan dan keterampilan abad ke-21 dalam matematika seperti kreativitas, berpikir kritis, kolaborasi dan komunikasi, serta pemecahan masalah dalam rangka revolusi industri 4.0 (Maryanto \& Siswanto, 2021) dan informasi, media dan keterampilan teknologi (Siswanto et al., 2019). Menurut Branca (Dwi Putra et al., 2018) Pemecahan masalah matematis merupakan salah satu kemampuan dasar yang harus dimiliki oleh peserta didik karena dianggap sebagai jantungnya matematika. Melalui pemecahan masalah diharapkan peserta didik dapat menemukan konsep matematika yang dipelajari (Hendriana, H., \& Sumarmo, 2014). Apabila peserta didik dapat menemukan konsep berarti mereka dapat memahami penggunaan konsep tersebut dalam menyelesaikan masalah. Salah satu tujuan belajar matematika itu adalah untuk melatih kemampuan pemecahan masalah peserta didik (Winarni, E. S., 2015). Berdasarkan pendapat-pendapat di atas maka kemampuan pemecahan masalah matematis menjadi salah satu fokus utama dalam pembelajaran matematika yang nantinya juga dapat diterapkan oleh peserta didik dalam memecahkan masalah-masalah yang terdapat dalam kehidupan sehari-hari.

Untuk saat ini kemampuan pemecahan masalah matematis peserta didik di Indonesia tergolong rendah. Berdasarkan hasil evaluasi lembaga Programme For International Student Assesment (PISA) pada tahun 2018 kompetensi peserta didik di Indonesia masih terbilang rendah, pada kompetensi untuk bidang matematika berada pada peringkat 72 dari 78 negara yang dievaluasi (OECD, 2020). Hasil evaluasi tersebut menunjukkan bahwa kemampuan pemecahan masalah matematis peserta didik di Indonesia dapat dikatakan rendah. Oleh karena itu perlu adanya evaluasi mengenai faktor-faktor yang mempengaruhi kemampuan pemecahan masalah matematis peserta didik untuk memperbaiki kompetensi dari peserta didik itu sendiri dan juga meningkatkan kualitas pembelajaran matematika.

Kemampuan pemecahan masalah matematis peserta didik dalam menyelesaikan soal matematika dapat dipengaruhi oleh beberapa faktor. Menurut Pimta, Tayruakham, dan Nuangchalerm (Meylina, 2019) :"Factors influencing mathematic problem-solving ability were represented as following: direct factors influencing mathematic problem-solving ability were described that direct and indirect factors influencing mathematic problem-solving ability were attitude towards mathematics, self-esteem and teachers teaching behavior. Indirect factors influencing mathematic problem-solving ability were motivation and selfefficacy". Berdasarkan pendapat tersebut terdapat faktor langsung dan faktor tidak langsung yang dapat mempengaruhi kemampuan pemecahan masalah matematis peserta didik. Faktor langsung yang mempengaruhi adalah sikap peserta didik dalam pembelajaran matematika, rasa percaya diri dan juga cara guru dalam mengajar, sikap dalam belajar matematika dapat disebut juga sebagai gaya berpikir dalam proses pembelajaran. Dalam memecahkan masalah matematika peserta didik memiliki cara dan gaya berpikir 
berbeda beda karena peserta didik tidak memiliki gaya berpikir yang sama (Ngilawajan, 2013). Oleh karena itu guru harus memperhatikan kegiatan mengajar yang dilakukannya karena para peserta didik memiliki cara berpikir yang berbeda dalam menerima dan mengelola informasi. Sedangkan faktor tidak langsung yang mempengaruhi adalah motivasi dan kemampuan diri. Motivasi dan kemampuan diri merupakan faktor yang berasal dari dalam diri peserta didik sehingga dapat dipengaruhi oleh karakteristik yang dimiliki. Karakteristik peserta didik tersebut dapat dikatakan sebagai tipe kepribadian.

Dalam penelitian ini, kemampuan pemecahan masalah matematis peserta didik akan diidentifikasi berdasarkan tipe kepribadian dengan menggunakan tipologi Hippocrates-Galenus. Menurut Kuntjojo (Amalia \& Widodo, 2018) dikenal dengan nama tipologi Hippocrates-Galenus karena sebenarnya Galenus meneruskan pendapat seorang filsuf di zaman yunani kuno, yang bernama Hypocrates, yang berpendapat bahwa di dalam tubuh manusia terdapat empat zat cair dengan sifat-sifat yang berlainan yaitu kering (empedu kuning), basah (empedu hitam), dingin (lendir), (4) panas (darah). Chomaria (2014) mengemukakan, berdasarkan empat macam cairan ini Galenus menggolongkan manusia atas empat tipe, yaitu (1) orang yang terlalu banyak chole sifatnya disebut choleris, (2) orang yang terlalu banyak sangui sifatnya disebut sanguinis, (3) orang yang terlalu banyak melanchole sifatnya disebut melancholis, (4) orang yang terlalu banyak flegma sifatnya disebut fhlegmatis. Dominasi dari salah satu cairan tersebut yang menyebabkan timbulnya ciri-ciri khas pada setiap orang. Berdasarkan pendapat di atas terdapat empat macam cairan dalam tubuh manusia yang dapat digolongkan berdasarkan sifatnya yaitu: 1) Sifat kering pada chole (empedu kuning) tergolong dalam choleris, 2) Sifat basah terdapat dalam melanchole (empedu hitam) yang tergolong dalam melancholis, 3) Sifat dingin terdapat dalam phlegma (lendir) yang tergolong dalam fhlegmatis, 4) Sifat panas terdapat dalam sanguis (darah) yang tergolong dalam sanguinis.

Untuk memahami berbagai temperamen yang melekat pada setiap cairan, berikut adalah gambaran klasifikasi manusia menurut empat bentuk cairan tersebut. Untuk tipe kepribadian koleris, cairan utama dalam tubuh adalah chole. Seorang koleris memiliki kepribadian yang khas, seperti antusiasme, kekakuan, lekas marah, agresif, optimis, galak, mudah tersinggung, mengendalikan keinginan, penguasa, kebencian, dan serius. Pada tipe kepribadian melankolis, cairan yang mendominasi dalam tubuh adalah cairan melanchole. Orang melankolis mengacu pada orang dengan tipe kepribadian seperti mudah kecewa, efektivitas tempur rendah, murung, pesimis, penakut, dan membosankan. Selanjutnya, pada kepribadian tipe plegmatis, cairan yang dominan dalam tubuh adalah phlegma. Orang dengan tipe kepribadian plegmatis adalah mereka yang memiliki kepribadian berbeda, seperti tidak mudah marah, tenang, tidak mudah terpengaruh, setia, dingin, santai dan sabar. Terakhir, pada tipe kepribadian sanguinis, cairan yang dominan dalam tubuh adalah cairan sanguis. Sanguinis adalah orang dengan tipe kepribadian, seperti mudah mengubah arah hidup, ramah, mudah bergaul, lincah, ceria, mudah tersenyum, tidak mudah putus asa (Septianawati, 2014).

Kemampuan pemecahan masalah matematis yang dimiliki oleh peserta didik berbeda-beda, terlebih peserta didik terdiri dari bermacam-macam karakteristik serta gender. Perbedaan gender bukan hanya berakibat pada kemampuan dalam matematika tetapi memperoleh pengetahuan matematika itu sendiri 
Identifikasi Pemecahan Masalah Matematis Peserta Didik Berdasarkan Tipe Kepribadian Hippocrates-Galenus dan Gender,

(Aliyah et al., 2019). Menurut Nur \& Pablo gender juga bisa menjadi faktor yang membedakan peserta didik dalam mengolah informasi dan belajar (Maryanto \& Siswanto, 2021a). Gender yang dimaksud dalam penelitian ini dibedakan menjadi laki-laki dan perempuan.

Berdasarkan hal ini peneliti tertarik untuk mengidentifikasi kemampuan pemecahan masalah matematis peserta didik berdasarkan karakteristik yang dimiliki oleh peserta didik berdasarkan tipologi kepribadian Hippocrates-Galenus. Adapun tujuan penelitian ini adalah mengidentifikasi dan mendeskripsikan kemampuan pemecahan masalah matematis peserta didik berdasarkan tipologi kepribadian Hippocrates-Galenus dan Gender.

\section{METODE}

Dalam penelitian ini metode yang digunakan adalah deskriptif kualitatif yang bertujuan untuk mendeskripsikan kemampuan pemecahan masalah matematis berdasarkan tipologi kepribadian Hippocrates-Galenus dan Gender. Penelitian ini dilakukan di SMP Negeri 13 Depok pada kelas VIII-D via Whatsapp Group untuk meminimalisir dan mencegah penularan Covid-19. Penentuan subjek penelitian menggunakan angket kepribadian Hippocrates-Galenus yang diadopsi dalam buku Personality Plus (Littauer, 2011). Kepribadian Hippocrates-Galenus digunakan untuk mengkategorikan peserta didik yang memiliki kepribadian sanguinis, koleris, melankolis, dan plegmatis. Peserta didik mengisi angket kepribadian melalui Google Form yang sudah dibuat oleh peneliti. Subjek yang didapat sebanyak 8 peserta didik, terdiri dari 4 peserta didik laki-laki yang memiliki kepribadian yang berbeda-beda, dan 4 peserta didik perempuan yang juga memiliki kepribadian yang berbeda-beda berdasarkan tipologi kepribadian Hippocrates-Galenus.

Tes kemampuan pemecahan masalah matematis yang dilakukan yaitu tes uraian berjumlah 4 soal dengan durasi 60 menit. Tujuan dari tes ini untuk mengukur kemampuan pemecahan masalah matematis dari subjek penelitian. Soal yang diberikan masing-masing sesuai indikator kemampuan pemecahan masalah matematis menurut Kesumawati (Chotimah, 2014) sebagai berikut:

Tabel 1. Indikator Kemampuan Pemecahan Masalah Matematis

\begin{tabular}{|l|l|l|}
\hline \multicolumn{1}{|c|}{ Ranah } & \multicolumn{1}{|c|}{ Aspek } & \multicolumn{1}{c|}{ Indikator } \\
\hline $\begin{array}{l}\text { Kemampuan Pemecahan } \\
\text { Masalah Matematis }\end{array}$ & $\begin{array}{l}\text { Menunjukkan } \\
\text { pemahaman masalah }\end{array}$ & $\begin{array}{l}\text { Meliputi kemampuan mengidentifikasi unsur- } \\
\text { unsur yang diketahui, ditanyakan, dan } \\
\text { kecukupan unsur yang diperlukan. }\end{array}$ \\
${$\cline { 2 - 3 }$} \begin{array}{l}\text { Mampu membuat atau } \\
\text { menyusun dan } \\
\text { matematika }\end{array} }$ & $\begin{array}{l}\text { Meliputi kemampuan merumuskan masalah } \\
\text { situasi sehari-hari dalam matematika. } \\
\text { memgembangkan strategi } \\
\text { pemecahan masalah }\end{array}$ & $\begin{array}{l}\text { Meliputi kemampuan memunculkan berbagai } \\
\text { kemungkinan atau alternatif cara } \\
\text { penyelesaian rumus-rumus atau pengetahuan } \\
\text { mana yang dapat digunakan dalam } \\
\text { pemecahan masalah tersebut. }\end{array}$ \\
\hline
\end{tabular}


Mampu menjelaskan dan memeriksa kebenaran jawaban yang diperoleh
Meliputi kemampuan mengidentifikasi kesalahan-kesalahan perhitungan, kesalahan penggunaan rumus, memeriksa kecocokan antara yang telah ditemukan dengan apa yang ditanyakan, dan dapat menjelaskan kebenaran jawaban tersebut.

Wawancara dilakukan dengan metode semi terstruktur dengan menggunakan panduan pada proses wawancara untuk menggali lebih dalam kemampuan pemecahan masalah matematis subjek, namun peneliti juga mengembangkan pertanyaan pada saat wawancara dengan alur pembahasan yang sesuai. Peneliti juga menggunakan dokumentasi sebagai alat bantu untuk mengumpulkan data berupa foto-foto hasil jawaban peserta didik dan voice note wawancara via Whatsapp.

Analisis data dalam penelitian ini menggunakan model Miles dan Huberman, yaitu reduksi data dan kategorisasi, penyajian data, penarikan kesimpulan atau verifikasi (Sugiyono, 2017). Teknik triangulasi dilakukan untuk melakukan keabsahan data yaitu dengan membandingkan hasil tes kemampuan pemecahan masalah matematis subjek dengan hasil wawancaranya.

\section{HASIL DAN DISKUSI}

Angket kepribadian diberikan kepada 26 peserta didik kelas VIII SMP Negeri 13 Depok via Google Form, kemudian peneliti memeriksa skor yang didapat dari setiap peserta didik, hal ini dilakukan untuk mengkategorikan peserta didik ke dalam tipologi kepribadian Hippocrates-Galenus yaitu sanguinis, koleris, melankolis, dan plegmatis serta gender yang sesuai dengan kriteria dan memenuhi syarat sampel yang diinginkan. Angket kepribadian ini menghasilkan 6 peserta didik yang memiliki tipe kepribadian sanguinis, 2 peserta didik dengan tipe kepribadian koleris, 9 peserta didik dengan tipe kepribadian melankolis, dan 9 peserta didik dengan tipe kepribadian plegmatis, kemudian peneliti memilih 8 peserta didik sebagai subjek penelitian seperti pada Tabel 1 yang terdiri dari 1 peserta didik sanguinis bergender laki-laki, 1 peserta didik sanguinis bergender perempuan, 1 peserta didik koleris bergender laki-laki, 1 peserta didik koleris bergender perempuan, 1 peserta didik melankolis bergender laki-laki, 1 peserta didik melankolis bergender perempuan, 1 peserta didik plegmatis bergender laki-laki, 1 peserta didik plegmatis bergender perempuan.

Tabel 2. Kategori Subjek Penelitian

\begin{tabular}{|c|c|c|c|c|c|c|c|}
\hline \multirow{2}{*}{ Subjek } & \multirow{2}{*}{ Nama } & \multirow{2}{*}{ Gender } & \multirow{2}{*}{ Skor } & \multicolumn{5}{|c|}{ Tipe Kepribadian } \\
\hline & & & Sanguinis & Koleris & Melankolis & Plegmatis \\
\hline 1 & HA & Laki-laki & 17 & $\checkmark$ & & & \\
\hline 2 & NSP & Perempuan & 17 & $\checkmark$ & & & \\
\hline 3 & FFS & Laki-laki & 13 & & $\checkmark$ & & \\
\hline 4 & AZA & Perempuan & 15 & & $\checkmark$ & & \\
\hline 5 & DBS & Laki-laki & 19 & & & $\checkmark$ & \\
\hline 6 & SFL & Perempuan & 16 & & & $\checkmark$ & \\
\hline 7 & DS & Laki-laki & 17 & & & & $\checkmark$ \\
\hline 8 & AIM & Perempuan & 22 & & & & $\checkmark$ \\
\hline
\end{tabular}


Identifikasi Pemecahan Masalah Matematis Peserta Didik Berdasarkan Tipe Kepribadian Hippocrates-Galenus dan Gender

Peneliti memberikan 4 pertanyaan mengenai kemampuan pemecahan masalah matematis sesuai dengan indikator yang sudah ditentukan kepada 8 subjek terpilih. Tes dan wawancara dilakukan menggunakan aplikasi Whatsapp, karena penelitian ini dilakukan saat pandemi COVID-19. Data hasil penelitian merupakan data hasil kemampuan pemecahan masalah matematis dan data hasil wawancara. Berikut akan disajikan pemaparan data hasil tes tertulis dan wawancara berdasarkan masing-masing indikator kemampuan pemecahan masalah matematis.

Pertanyaan nomor 1 tes kemampuan pemecahan masalah matematis mengenai indikator kemampuan mengidentifikasi unsur-unsur yang diketahui, ditanyakan, dan kecukupan unsur yang diperlukan, sebagai berikut: menentukan panjang salah satu sisi segitiga dari dua bangun segitiga berdasarkan gambar yang terdapat pada soal. Jawaban tertulis pertanyaan nomor 1 dari S2 disajikan pada Gambar 1 dan cuplikan wawancara pertanyaan nomor 1 untuk S2 disajikan pada Tabel 2.

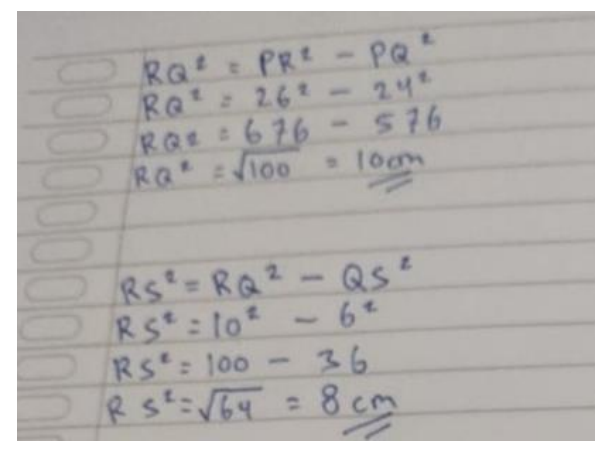

Gambar 1. Jawaban Pertanyaan Nomor 1 dari S2

Berdasarkan jawaban tertulis dari S2 pada Gambar 2, menunjukkan bahwa S2 tidak mengidentifikasi unsur-unsur yang diketahui dan ditanyakan dalam soal karena tidak tertulis apa saja yang diketahui dan ditanyakan namun kecukupan unsur yang diperlukan dalam soal dapat dijawab dengan benar. Berdasarkan jawaban yang diberikan S2 pada Gambar 2, peneliti melakukan wawancara kepada S2.

Tabel 3. Cuplikan Wawancara Pertanyaan Nomor 1 untuk S2

\begin{tabular}{|c|l|}
\hline \multicolumn{1}{|c|}{ Subjek 2 } \\
\hline $\mathrm{P}:$ & $\begin{array}{l}\text { Sebelumnya kamu sudah pernah mengerjakan soal-soal seperti ini? Menurut kamu soal } \\
\text { yang dikerjakan mudah, sedang atau sulit? }\end{array}$ \\
\hline $\mathrm{S} 2:$ & $\begin{array}{l}\text { Di soal yang kakak kasih ada 2 soal yang udah pernah dikasih sama guru buat ulangan } \\
\text { harian. Sedang kak, soalnya saya suka rumus akar kuadrat yang ada di dalam pythagoras. }\end{array}$ \\
\hline $\mathrm{P}:$ & $\begin{array}{l}\text { Coba jelaskan apa saja yang diketahui, ditanyakan dan juga proses pengerjaan untuk soal } \\
\text { nomor 1! }\end{array}$ \\
\hline $\mathrm{S} 2:$ & $\begin{array}{l}\mathrm{RQ}^{2}=\mathrm{PR}^{2}-\mathrm{PQ}^{2}=26^{2}-24^{2}=26 \times 26-24 \times 24=676-576=100, \text { dan } 100 \text { di akar } \\
\text { kuadratin jadi } 10 . \mathrm{RS}^{2}=\mathrm{RQ}^{2}-\mathrm{QS}^{2}=10^{2}-6^{2}=10 \times 10-6 \times 6=100-36=64,64 \text { di akar } \\
\text { kuadratin jadi 8. }\end{array}$ \\
\hline
\end{tabular}

Berdasarkan cuplikan wawancara pertanyaan nomor 1 untuk S2, terlihat bahwa S2 tidak menyebutkan unsur-unsur yang diketahui dan ditanyakan namun S2 dapat menjelaskan proses pengerjaan sehingga kecukupan unsur yang diperlukan dapat dijawab dengan terperinci dan juga benar. Selanjutnya, 
jawaban tertulis pertanyaan nomor 1 dari S4 disajikan pada Gambar 2 dan cuplikan wawancara pertanyaan nomor 1 untuk S4 disajikan pada Tabel 3.

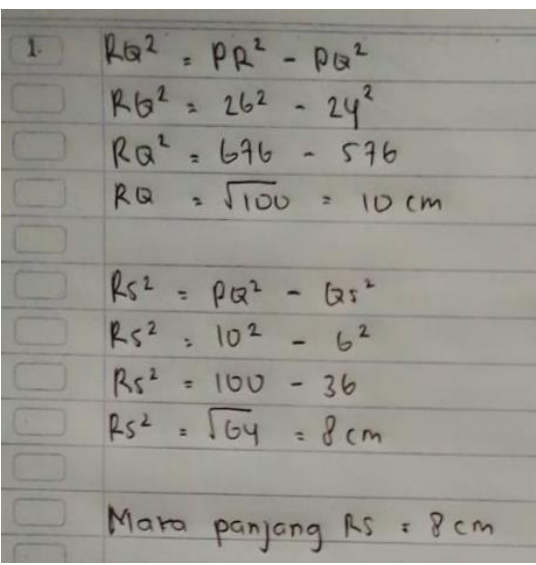

Gambar 2. Jawaban Pertanyaan Nomor 1 dari S4

Berdasarkan jawaban tertulis dari S4 pada Gambar 2, menunjukkan bahwa S4 tidak mengidentifikasi unsur-unsur yang diketahui dan ditanyakan dalam soal karena tidak tertulis apa saja yang diketahui dan ditanyakan namun kecukupan unsur yang diperlukan dalam soal dapat dijawab dengan benar. Berdasarkan jawaban yang diberikan S4 pada Gambar 2, peneliti melakukan wawancara kepada S4.

Tabel 4. Cuplikan Wawancara Pertanyaan Nomor 1 untuk S4

\begin{tabular}{|c|l|}
\hline \multicolumn{2}{|c|}{ Subjek 4 } \\
\hline P: & $\begin{array}{l}\text { Sebelumnya kamu sudah pernah mengerjakan soal-soal seperti ini? Menurut kamu soal } \\
\text { yang dikerjakan mudah, sedang atau sulit? }\end{array}$ \\
\hline S4: & $\begin{array}{l}\text { Kalo di sekolah udah pernah kak tapi kalo kayak gini belom pernah. Kalo menurut saya } \\
\text { gak terlalu susah sih kak cuma beberapa ada yang sulit. }\end{array}$ \\
\hline P: & Apa yang kamu pahami dari soal nomor 1? \\
\hline S4: & Kalo yang nomor 1 itu menentukan hipotenusa nya. \\
\hline P: & $\begin{array}{l}\text { Coba jelaskan apa saja yang diketahui, ditanyakan dan juga proses pengerjaan untuk soal } \\
\text { nomor 1! }\end{array}$ \\
\hline S4: & $\begin{array}{l}\text { Nomor 1 yang diketahui PR = 26, PQ = 24. RQ nya belum ditemukan karena itu kita harus } \\
\text { menemukan RQ terlebih dahulu. Setelah RQ ketemu lanjut untuk mencari RS, yang ditanya } \\
\text { pada nomor 1 adalah RS. }\end{array}$ \\
\hline
\end{tabular}

Berdasarkan cuplikan wawancara pertanyaan nomor 1 untuk S4, terlihat bahwa S4 dapat menyebutkan unsur-unsur yang diketahui dan yang ditanyakan dalam soal meskipun tidak lengkap, S4 menjelaskan tahapan proses pengerjaan meskipun tidak secara spesifik sehingga memenuhi pemahaman kecukupan unsur dalam proses wawancara. Selanjutnya, jawaban tertulis pertanyaan nomor 1 dari S6 disajikan pada Gambar 3 dan cuplikan wawancara pertanyaan nomor 1 untuk S6 disajikan pada Tabel 4. 


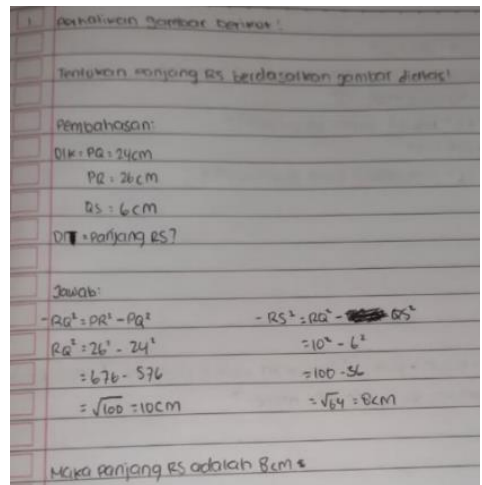

Gambar 3. Jawaban Pertanyaan Nomor 1 dari S6

Berdasarkan jawaban tertulis dari S6 pada Gambar 3, menunjukkan bahwa S6 dapat mengidentifikasi unsur-unsur yang diketahui dan ditanyakan dalam soal serta kecukupan unsur yang diperlukan dalam soal dapat dijawab dengan benar. Berdasarkan jawaban yang diberikan S6 pada Gambar 3, peneliti melakukan wawancara kepada S6.

Tabel 5. Cuplikan Wawancara Pertanyaan Nomor 1 untuk S6

\begin{tabular}{|c|l|}
\hline \multicolumn{1}{|c|}{ Subjek 6} \\
\hline P: & $\begin{array}{l}\text { Sebelumnya kamu sudah pernah mengerjakan soal-soal seperti ini? Menurut kamu soal } \\
\text { yang dikerjakan mudah, sedang atau sulit? }\end{array}$ \\
\hline S6: & Udah kak. Sedang sih kak lumayan sulit. \\
\hline P: & $\begin{array}{l}\text { Coba jelaskan apa saja yang diketahui, ditanyakan dan juga proses pengerjaan untuk soal } \\
\text { nomor 1! }\end{array}$ \\
\hline S6: & Diketahui nomor 1 panjang PQ $=24 \mathrm{~cm}$, panjang PR $=26 \mathrm{~cm}$, panjang QS $=6 \mathrm{~cm}$. \\
\hline
\end{tabular}

Berdasarkan cuplikan wawancara pertanyaan nomor 1 untuk S6, terlihat bahwa S6 menyebutkan unsur-unsur yang diketahui namun tidak menyebutkan yang ditanyakan dalam soal, S6 juga tidak menjelaskan tahapan proses pengerjaan sehingga tidak memenuhi pemahaman kecukupan unsur dalam proses wawancara. Selanjutnya, jawaban tertulis pertanyaan nomor 1 dari S8 disajikan pada Gambar 4 dan cuplikan wawancara pertanyaan nomor 1 untuk S8 disajikan pada Tabel 5.

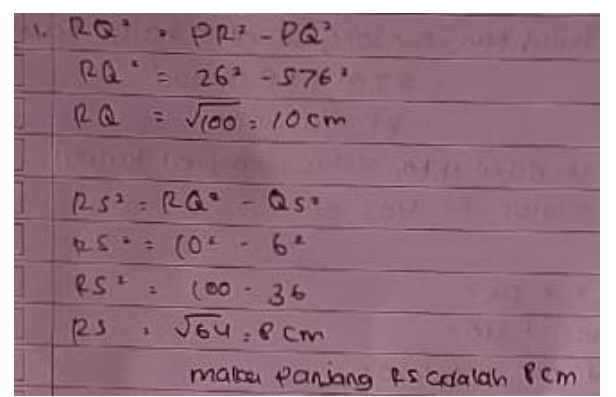

Gambar 4. Jawaban Pertanyaan Nomor 1 dari S8

Berdasarkan jawaban tertulis dari S8 pada Gambar 4, menunjukkan bahwa S8 tidak mengidentifikasi unsur-unsur yang diketahui dan ditanyakan dalam soal namun kecukupan unsur yang diperlukan dalam soal dapat dijawab dengan benar. Berdasarkan jawaban yang diberikan S8 pada Gambar 4, peneliti melakukan wawancara kepada S8. 
Tabel 6. Cuplikan Wawancara Pertanyaan Nomor 1 untuk S8

\begin{tabular}{|c|l|}
\hline \multicolumn{1}{|c|}{ Subjek 8} \\
\hline P: & $\begin{array}{l}\text { Sebelumnya kamu sudah pernah mengerjakan soal-soal seperti ini? Menurut kamu soal } \\
\text { yang dikerjakan mudah, sedang atau sulit? }\end{array}$ \\
\hline S8: & $\begin{array}{l}\text { Ada yang udah ngerjain ada yang belom ngerjain kak. Sulit karena ada beberapa yang } \\
\text { belum di mengerti. }\end{array}$ \\
\hline P: & Kira-kira kesulitannya dimana? \\
\hline S8: & $\begin{array}{l}\text { Kesulitannya ada di nomor 2 karena ada yang tripel pythagoras dan ada yang bukan tripel } \\
\text { pythagoras. }\end{array}$ \\
\hline P: & $\begin{array}{l}\text { Sekarang coba jelaskan apa saja yang diketahui, ditanyakan dan juga proses pengerjaan } \\
\text { untuk soal nomor 1! }\end{array}$ \\
\hline S8: & $\begin{array}{l}\text { Jadi nomor 1 itu yang ditanyain nya panjang RS, cara nyelesaiinnya adalah dengan } \mathrm{RQ}^{2}= \\
\mathrm{PR}^{2}-\mathrm{PQ}^{2} \text { setelah itu kalau udah di jumlahin, hasilnya adalah RS =64, 64 di akar kuadratin } \\
\text { jadi } 8 \mathrm{~cm} .\end{array}$ \\
\hline
\end{tabular}

Berdasarkan cuplikan wawancara pertanyaan nomor 1 untuk S8, terlihat bahwa S8 tidak menyebutkan unsur-unsur yang diketahui namun tidak menyebutkan yang ditanyakan dalam soal, S8 menjelaskan tahapan proses pengerjaan meskipun tidak secara terperinci tetapi tetap memenuhi pemahaman kecukupan unsur dalam proses wawancara.

Pertanyaan nomor 2 tes kemampuan pemecahan masalah matematis mengenai indikator kemampuan mengidentifikasi kesalahan-kesalahan perhitungan, kesalahan penggunaan rumus, memeriksa kecocokan antara yang telah ditemukan dengan apa yang ditanyakan, dan dapat menjelaskan kebenaran jawaban, sebagai berikut: "Berikut ini adalah ukuran sisi-sisi segitiga. a) $6 \mathrm{~cm}, 8 \mathrm{~cm}, 10 \mathrm{~cm}$, b) $7 \mathrm{~cm}, 12$ $\mathrm{cm}, 13 \mathrm{~cm}$, c) $8 \mathrm{~cm}, 15 \mathrm{~cm}, 17 \mathrm{~cm}$. Tentukan triple pythagoras berdasarkan ukuran sisi-sisi segitiga di atas, berikut alasannya". Jawaban tertulis pertanyaan nomor 2 dari S2 disajikan pada Gambar 5 dan cuplikan wawancara pertanyaan nomor 2 untuk S2 disajikan pada Tabel 6.

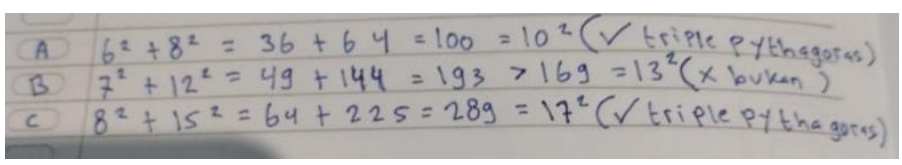

Gambar 5. Jawaban Pertanyaan Nomor 2 dari S2

Berdasarkan jawaban tertulis dari S2 pada Gambar 5, menunjukkan bahwa S2 dapat mengidentifikasi kesalahan-kesalahan perhitungan, memeriksa kecocokan antara yang telah ditemukan dengan apa yang ditanyakan, dan dapat menjelaskan kebenaran jawaban yang terdapat dalam soal dengan benar. Berdasarkan jawaban yang diberikan S2 pada Gambar 5, peneliti melakukan wawancara kepada S2.

Tabel 7. Cuplikan Wawancara Pertanyaan Nomor 2 untuk S2

\begin{tabular}{|c|l|}
\hline \multicolumn{2}{|c|}{ Subjek 2 } \\
\hline P: & $\begin{array}{l}\text { Sekarang coba jelaskan apa saja yang diketahui, ditanyakan dan juga proses pengerjaan } \\
\text { untuk soal nomor 2! }\end{array}$ \\
\hline S2: & $\begin{array}{l}\text { Nomor 2, yang merupakan triple pythagoras adalah (a) dan (c) karna (a) dan (c) adalah } \mathrm{A}^{2} \\
+\mathrm{B}^{2}=\mathrm{C}^{2} \text { karna rumus itu merupakan triple pythagoras. }\end{array}$ \\
\hline $\mathrm{P}:$ & $\begin{array}{l}\text { Trus kamu yakin gak sama jawaban yang udah kamu kerjain itu kalo jawaban yang udah } \\
\text { kamu kerjain itu udah benar? }\end{array}$ \\
\hline S2: & Di bagian akar kuadrat dalam pythagoras nya saya yakin kak. \\
\hline
\end{tabular}


Identifikasi Pemecahan Masalah Matematis Peserta Didik Berdasarkan Tipe Kepribadian Hippocrates-Galenus dan Gender,

\begin{tabular}{|c|l|}
\hline P: & Kamu sudah memeriksa kembali jawabannya? \\
\hline S2: & Sudah kak. \\
\hline
\end{tabular}

Berdasarkan cuplikan wawancara pertanyaan nomor 2 untuk S2, terlihat bahwa S2 menjelaskan dengan sederhana mengenai kecocokan jawaban dengan apa yang ditanyakan sedangkan untuk kesalahankesalahan perhitungan pada soal tidak dijelaskan, S2 juga telah memeriksa kembali kebenaran jawaban yang telah diperolehnya dengan yakin. Selanjutnya, jawaban tertulis pertanyaan nomor 2 dari S4 disajikan pada Gambar 6 dan cuplikan wawancara pertanyaan nomor 2 untuk S4 disajikan pada Tabel 7.

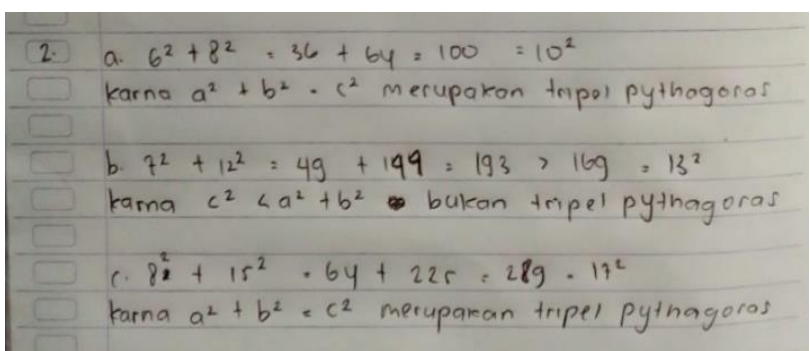

Gambar 6. Jawaban Pertanyaan Nomor 2 dari S4

Berdasarkan jawaban tertulis dari S4 pada Gambar 6, menunjukkan bahwa S4 dapat mengidentifikasi kesalahan-kesalahan perhitungan, memeriksa kecocokan antara yang telah ditemukan dengan apa yang ditanyakan, dan dapat menjelaskan kebenaran jawaban yang terdapat dalam soal dengan benar. Berdasarkan jawaban yang diberikan S4 pada Gambar 6, peneliti melakukan wawancara kepada S4.

Tabel 8. Cuplikan Wawancara Pertanyaan Nomor 2 untuk S4

\begin{tabular}{|c|l|}
\hline \multicolumn{1}{|c|}{ Subjek 4 } \\
\hline P: & $\begin{array}{l}\text { Sekarang coba jelaskan apa saja yang diketahui, ditanyakan dan juga proses pengerjaan } \\
\text { untuk nomor 2! }\end{array}$ \\
\hline S4: & $\begin{array}{l}\text { Diketahui bagian (a) 6, 8,10 bagian (b) 7, 12, 13 bagian (c) } 8,15,17 \text {. Yang ditanya adalah } \\
\text { "tentukan yang memenuhi triple pythagoras berdasarkan ukuran sisi segitiga di atas". } \\
\text { Alasannya karena untuk yang bagian (a) karna A + B = C artinya A + B hasilnya itu sama } \\
\text { dengan C merupakan triple pythagoras. Untuk yang bagian (b) karna C < A + B maka } \\
\text { bukan triple pythagoras. Untuk yang bagian (c) karna A + B = C merupakan triple } \\
\text { pythagoras artinya yang triple pythagoras itu sama jumlah A + B = C itu sama. }\end{array}$ \\
\hline $\mathrm{P}:$ & $\begin{array}{l}\text { Trus kamu yakin gak sama jawaban yang udah kamu kerjain itu kalo jawaban yang udah } \\
\text { kamu kerjain itu udah benar? Kamu sudah memeriksa kembali jawabannya? }\end{array}$ \\
\hline S4: & $\begin{array}{l}\text { Insya Allah saya yakin kak, karna saya udah mengecek berkali-kali tadi juga awalnya saya } \\
\text { belom yakin banget karna masih ragu, akhirnya saya cek lagi ternyata emang bener kayak } \\
\text { ada yang salah gitu akhirnya saya ulangin lagi dan sekarang saya udah yakin kalo itu Insya } \\
\text { Allah jawabannya udah bener. }\end{array}$ \\
\hline
\end{tabular}

Berdasarkan cuplikan wawancara pertanyaan nomor 2 untuk S4, terlihat bahwa S4 dapat menjelaskan secara sederhana mengenai kesalahan-kesalahan perhitungan dalam soal dan kecocokan jawaban dengan apa yang ditanyakan, S4 juga telah memeriksa kembali kebenaran jawaban yang telah diperolehnya dengan yakin. Selanjutnya, jawaban tertulis pertanyaan nomor 2 dari S6 disajikan pada Gambar 7 dan cuplikan wawancara pertanyaan nomor 2 untuk S6 disajikan pada Tabel 8. 


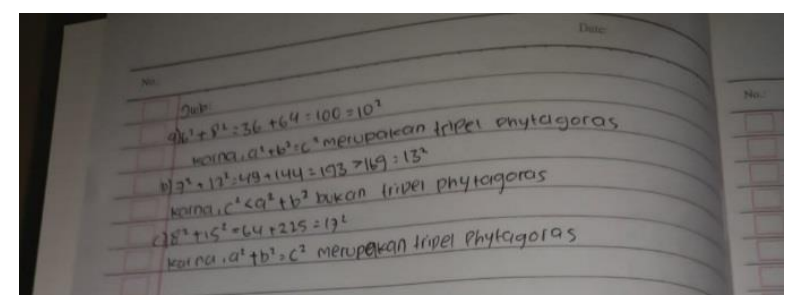

Gambar 7. Jawaban Pertanyaan Nomor 2 dari S6

Berdasarkan jawaban tertulis dari S6 pada Gambar 7, menunjukkan bahwa S6 dapat mengidentifikasi kesalahan-kesalahan perhitungan, memeriksa kecocokan antara yang telah ditemukan dengan apa yang ditanyakan serta menjelaskan kebenaran jawaban yang terdapat dalam soal dengan benar. Berdasarkan jawaban yang diberikan S6 pada Gambar 7, peneliti melakukan wawancara kepada S6.

Tabel 9. Cuplikan Wawancara Pertanyaan Nomor 2 untuk S6

\begin{tabular}{|c|l|}
\hline \multicolumn{1}{|c|}{ Subjek 6 } \\
\hline P: & $\begin{array}{l}\text { Sekarang coba jelaskan apa saja yang diketahui, ditanyakan dan juga proses pengerjaan } \\
\text { pada nomor 2! }\end{array}$ \\
\hline S6: & $\begin{array}{l}\text { Diketahui nomor 2 ukuran sisi-sisi segitiga, yang (a) } 6 \mathrm{~cm}, 8 \mathrm{~cm} \text { dan } 10 \mathrm{~cm} \text {, ukuran sisi } \\
\text { segitiga yang (b) 7, 12, 13, ukuran sisi-sisi segitiga yang (c) } 8,15,17 .\end{array}$ \\
\hline P: & $\begin{array}{l}\text { Trus kamu yakin gak sama jawaban yang udah kamu kerjain itu kalo jawaban yang udah } \\
\text { kamu kerjain itu udah benar? Kamu sudah memeriksa kembali jawabannya? }\end{array}$ \\
\hline S6: & $\begin{array}{l}\text { Saya udah cukup yakin dengan jawabannya karna tadi sebelum saya ngumpulin saya sudah } \\
\text { periksa soal dan jawabannya beberapa kali. }\end{array}$ \\
\hline
\end{tabular}

Berdasarkan cuplikan wawancara pertanyaan nomor 2 untuk S6, terlihat bahwa S6 tidak menjelaskan mengenai kesalahan-kesalahan perhitungan dalam soal dan kecocokan jawaban dengan apa yang ditanyakan melainkan hanya menyebutkan apa saja yang diketahui dalam soal, S6 telah memeriksa kembali kebenaran jawaban yang telah diperolehnya dengan cukup yakin.

Selanjutnya, jawaban tertulis pertanyaan nomor 2 dari S8 disajikan pada Gambar 8 dan cuplikan wawancara pertanyaan nomor 2 untuk S8 disajikan pada Tabel 9.

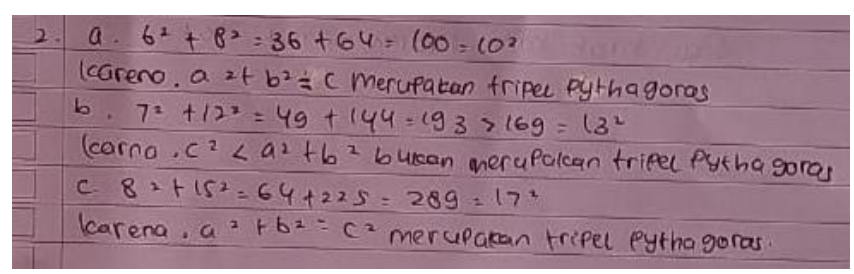

Gambar 8. Jawaban Pertanyaan Nomor 2 dari S8

Berdasarkan jawaban tertulis dari S8 pada Gambar 8, menunjukkan bahwa S8 dapat mengidentifikasi kesalahan-kesalahan perhitungan, memeriksa kecocokan antara yang telah ditemukan dengan apa yang ditanyakan serta dapat menjelaskan kebenaran jawaban yang terdapat dalam soal dengan baik. Berdasarkan jawaban yang diberikan S8 pada Gambar 8, peneliti melakukan wawancara kepada S8.

Tabel 10. Cuplikan Wawancara Pertanyaan Nomor 2 untuk S8

\begin{tabular}{|c|l|}
\hline \multicolumn{1}{|c|}{ Subjek 8 } \\
\hline P: & $\begin{array}{l}\text { Sekarang coba jelaskan apa saja yang diketahui, ditanyakan dan juga proses pengerjaan } \\
\text { untuk soal nomor 2! }\end{array}$ \\
\hline
\end{tabular}




\begin{tabular}{|c|l|}
\hline S8: & $\begin{array}{l}\text { Nomor 2 ditanyainnya tentukan yang memenuhi triple pythagoras, jadi harus ditentuin (a), } \\
\text { (b) sama (c) nya. Yang (a) nya itu adalah } 6^{2}+8^{2}=36+64 \text { hasilnya 100, nah yang 100 nya } \\
\text { itu di pangkatin } 2 \text { karna } \mathrm{A}^{2}+\mathrm{B}^{2}=\mathrm{C}^{2} \text { itu merupakan triple pythagoras. yang (b) itu } 7^{2}+12^{2} \\
=49+144 \text { hasilnya itu } 193, \text { nah jadi hasilnya } 13^{2} \text { karna } \mathrm{C}^{2}=\mathrm{A}^{2}+\mathrm{B}^{2} \text { merupakan triple } \\
\text { pythagoras, sedangkan yang (c) } 8^{2}+15^{2}=64+225 \text { hasilnya itu kan } 289, \text { jadi } 17 \\
\text { dipangkatin 2 hasilnya } 289 \text { jadi jawabannya karna } \mathrm{A}^{2}+\mathrm{B}^{2}=\mathrm{C}^{2} \text { merupakan triple } \\
\text { pythagoras. }\end{array}$ \\
\hline $\mathrm{P}:$ & $\begin{array}{l}\text { Trus kamu yakin gak sama jawaban yang udah kamu kerjain itu kalo jawaban yang udah } \\
\text { kamu kerjain itu udah benar? Kamu sudah memeriksa kembali jawabannya? }\end{array}$ \\
\hline S8: & $\begin{array}{l}\text { Kalo soal itu udah yakin soalnya kan sebelum ngerjain ngeliat soalnya dulu trus nyari } \\
\text { rumusnya abis itu setelah selesai ngerjain di cek lagi, dibenerin lagi kalo misalkan ada yang } \\
\text { salah. Dan juga udah yakin soalnya udah ngikutin sesuai rumusnya. }\end{array}$ \\
\hline
\end{tabular}

Berdasarkan cuplikan wawancara pertanyaan nomor 2 untuk S8, terlihat bahwa S8 dapat menjelaskan mengenai kesalahan-kesalahan perhitungan dan kecocokan jawaban dengan yang ditanyakan meskipun ada beberapa kesalahan penyebutan, S8 juga telah memeriksa kembali kebenaran jawaban yang telah diperolehnya dengan yakin.

Pertanyaan nomor 3 tes kemampuan pemecahan masalah matematis mengenai indikator kemampuan dalam memunculkan beberapa kemungkinan atau alternatif penyelesaian rumus-rumus maupun pengetahuan yang dapat digunakan dalam pemecahan masalah, sebagai berikut: "Sebuah tiang bendera akan di isi kawat penyangga agar tidak roboh seperti gambar di bawah ini. Jika jarak kaki tiang dengan kaki kawat penyangga adalah $8 \mathrm{~m}$, jarak kaki tiang dengan ujung kawat penyangga pertama $6 \mathrm{~m}$ dan jarak kawat penyangga pertama dengan kawat penyangga kedua adalah $9 \mathrm{~m}$. Hitunglah panjang total kawat yang diperlukan dan hitunglah biaya yang diperlukan jika harga kawat Rp. 15.000 per meter!". Jawaban tertulis pertanyaan nomor 3 dari S2 disajikan pada Gambar 9 dan cuplikan wawancara pertanyaan nomor 3 untuk S2 disajikan pada Tabel 10.

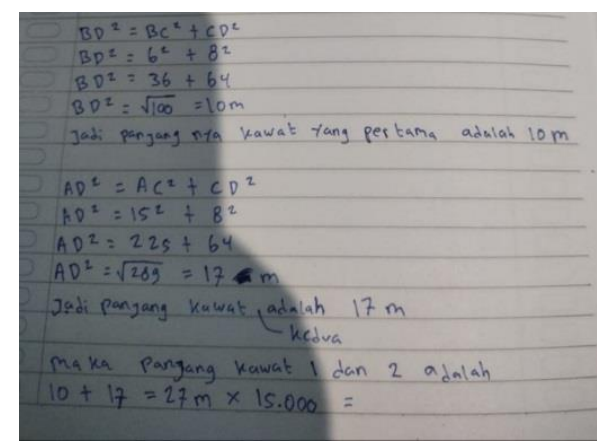

Gambar 9. Jawaban Pertanyaan Nomor 3 dari S2

Berdasarkan jawaban tertulis dari S2 pada Gambar 9, menunjukkan bahwa S2 dapat memunculkan alternatif penyelesaian menggunakan rumus-rumus yang telah diketahuinya serta pengetahuan yang digunakan dalam pemecahan masalah dengan cukup baik namun hasil akhir tidak dituliskan pada jawabannya. Berdasarkan jawaban yang diberikan S2 pada Gambar 9, peneliti melakukan wawancara kepada $\mathrm{S} 2$. 
Tabel 11. Cuplikan Wawancara Pertanyaan Nomor 3 untuk S2

\begin{tabular}{|c|l|}
\hline \multicolumn{1}{|c|}{ Subjek 2 } \\
\hline $\mathrm{P}:$ & $\begin{array}{l}\text { Sekarang coba jelaskan apa saja yang diketahui, ditanyakan dan juga proses pengerjaan } \\
\text { untuk soal nomor 3! }\end{array}$ \\
\hline $\mathrm{S} 2:$ & $\begin{array}{l}\text { Yang kawat pertama adalah } \mathrm{BD}^{2}=\mathrm{BC}^{2}+\mathrm{CD}^{2}=6^{2}+8^{2}=6 \times 6+8 \times 8=36+64=100, \\
\text { 100 di akar kuadrat adalah 10. Jumlah tiang kedua adalah } 17 \text { karna kan } \mathrm{AD}^{2}=\mathrm{AC}^{2}+\mathrm{CD}^{2} \\
\text { kawat satu dan dua adalah 10 ditambah 17 sama dengan 27, 27 x 15.000 jadi totalnya adalah } \\
\text { 405.000. }\end{array}$ \\
\hline $\mathrm{P}:$ & Menurut kamu bagian tersulit dalam soal ini apa? \\
\hline $\mathrm{S} 2:$ & Rumus pythagoras agak sulit kak di pahami, saya lebih ngerti akar kuadrat. \\
\hline
\end{tabular}

Berdasarkan cuplikan wawancara pertanyaan nomor 3 untuk S2, terlihat bahwa S2 dapat menjelaskan mengenai alternatif penyelesaian penggunaan rumus yang telah diketahuinya serta pengetahuan yang digunakan dalam memecahankan masalah dengan cukup jelas. Selanjutnya, jawaban tertulis pertanyaan nomor 3 dari S4 disajikan pada Gambar 10 dan cuplikan wawancara pertanyaan nomor 3 untuk S4 disajikan pada Tabel 11.

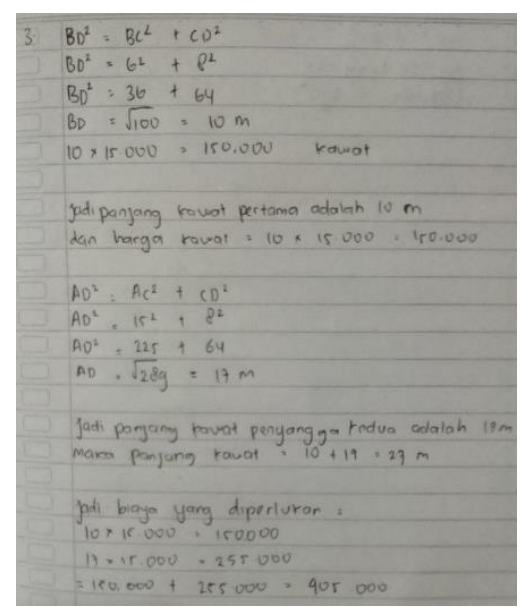

Gambar 10. Jawaban Pertanyaan Nomor 3 dari S4

Berdasarkan jawaban tertulis dari S4 pada Gambar 10, menunjukkan bahwa S4 dapat memunculkan alternatif penyelesaian menggunakan rumus-rumus yang telah diketahuinya serta pengetahuan yang digunakan dalam pemecahan masalah dengan sangat baik. Berdasarkan jawaban yang diberikan S4 pada Gambar 10, peneliti melakukan wawancara kepada S4.

Tabel 12. Cuplikan Wawancara Pertanyaan Nomor 3 untuk S4

\begin{tabular}{|c|l|}
\hline \multicolumn{1}{|c|}{ Subjek 4 } \\
\hline P: & $\begin{array}{l}\text { Sekarang coba jelaskan apa saja yang diketahui, ditanyakan dan juga proses pengerjaan } \\
\text { yang nomor 3! }\end{array}$ \\
\hline S4: & $\begin{array}{l}\text { Jarak tiang dengan kaki kawat penyangga adalah 8 m, jarak kaki tiang dengan ujung kawat } \\
\text { penyangga pertama adalah 6 m dan jarak kawat penyangga kedua adalah 9 m. Yang ditanya } \\
\text { hitunglah kawat penyangga yang diperlukan dan biaya yang diperlukan jika harga kawat } \\
\text { Rp. 15.000 per meter. }\end{array}$ \\
\hline P: & Coba jelasin strategi kamu saat ngerjain soal ini? \\
\hline S4: & $\begin{array}{l}\text { Strategi awalnya saya mengerjakan, saya menghafal kuadrat dari akar pangkat kuadrat } \\
\text { dulu. Untuk nomor 3 nya itu saya menentukan BD dulu setelah itu hasil BD nya itu saya } \\
\text { kali dengan harga kawat yaitu 15.000. setelah itu saya menentukan AD, hasil AD nya }\end{array}$ \\
\hline
\end{tabular}


dikalikan dengan 15.000 , jadi totalnya harga kawat penyangga pertama di tambah harga kawat penyangga kedua.

Berdasarkan cuplikan wawancara pertanyaan nomor 3 untuk S4, terlihat bahwa S4 dapat memahami isi soal cerita dengan baik sehingga dapat menjelaskan mengenai alternatif penyelesaian penggunaan rumus serta pengetahuan yang digunakan dalam memecahkan masalah yang diberikan meskipun tidak disebutkan hasil akhir dalam jawaban yang diperolehnya. Selanjutnya, jawaban tertulis pertanyaan nomor 3 dari S6 disajikan pada Gambar 11 dan cuplikan wawancara pertanyaan nomor 3 untuk S6 disajikan pada Tabel 12.

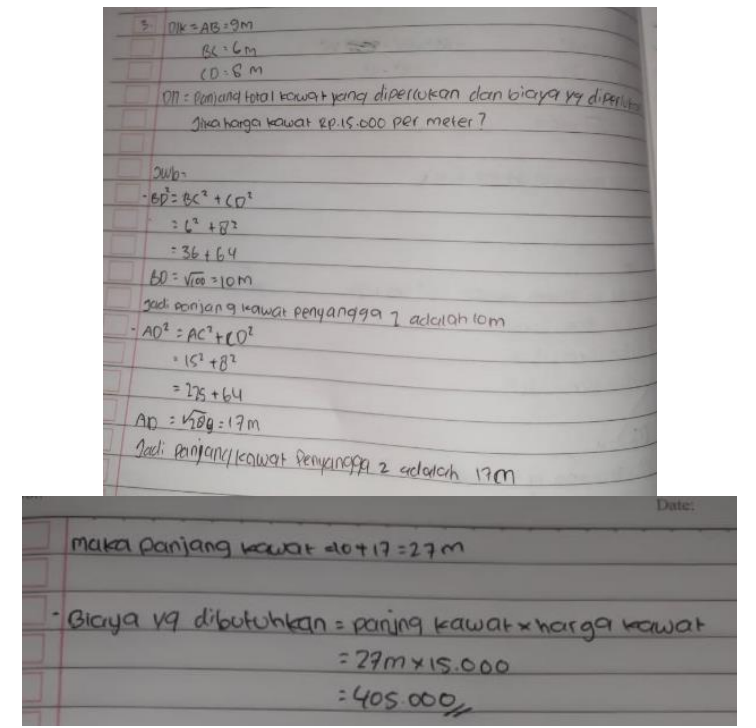

Gambar 11. Jawaban Pertanyaan Nomor 3 dari S6

Berdasarkan jawaban tertulis dari S6 pada Gambar 11, menunjukkan bahwa S6 dapat memunculkan alternatif penyelesaian menggunakan rumus-rumus yang telah diketahuinya serta pengetahuan yang digunakan dalam pemecahan masalah dengan sangat baik. Berdasarkan jawaban yang diberikan S6 pada Gambar 11, peneliti melakukan wawancara kepada S6.

Tabel 13. Cuplikan Wawancara Pertanyaan Nomor 3 untuk S6

\begin{tabular}{|c|c|}
\hline \multicolumn{2}{|r|}{ Subjek 6} \\
\hline P: & $\begin{array}{l}\text { Sekarang coba jelaskan apa saja yang diketahui, ditanyakan dan juga proses pengerjaan } \\
\text { untuk soal nomor } 3 \text { ! }\end{array}$ \\
\hline S6: & $\begin{array}{l}\text { Jadi di sini ada gambar sebuah tiang bendera yang akan diisi kawat penyangga supaya tidak } \\
\text { rubuh, jika jarak kaki tiang dengan kaki kawat penyangga adalah } 8 \mathrm{~m} \text { dan jarak kaki tiang } \\
\text { dengan ujung kawat penyangga pertama adalah } 6 \mathrm{~m} \text { dan jarak kawat penyangga pertama } \\
\text { dan kedua adalah } 9 \mathrm{~m} \text {. Hitunglah kawat penyangga yang diperlukan dan biaya yang } \\
\text { diperlukan jika harga kawat Rp. } 15.000 \text { per meternya. Pembahasan diketahui panjang } \mathrm{AB} \\
=9 \mathrm{~m} \text {, panjang } \mathrm{BC}=6 \mathrm{~m} \text {, dan panjang } \mathrm{CD}=8 \mathrm{~m} \text {. Di sini kita disuruh mencari panjang } \\
\text { kawat penyangga pertama rumusnya } \mathrm{BD}^{2}=\mathrm{BC}^{2}+\mathrm{CD}^{2}=6^{2}+8^{2}=36+64=100,100 \\
\text { diakar kuadratkan sama dengan } 10 \text {, jadi panjang kawat penyangga pertama adalah } 10 \mathrm{~m} \text {. } \\
\text { Lanjut mencari panjang kawat penyangga kedua } \mathrm{AD}^{2}=\mathrm{AC}^{2}+\mathrm{CD}^{2}=15^{2}+8^{2}=225+64 \\
=289,289 \text { di akar kuadratkan sama dengan } 17 \text {, jadi panjang kawat penyangga kedua adalah } \\
17 \mathrm{~m} \text {. Maka panjang kawat penyangga seluruhnya adalah } 10 \mathrm{~m}+17 \mathrm{~m}=27 \mathrm{~m} \text {. Biaya yang } \\
\text { dibutuhkan } 27 \mathrm{~m} \times 15.000=\text { Rp. } 405.000 .\end{array}$ \\
\hline P: & Menurut kamu bagian tersulit dalam soal ini apa? \\
\hline
\end{tabular}


S6:

Di jawabannya sih itu kan tadinya harus dicari dulu kawat penyangga satunya, saya langsung ke penyangga duanya jadi gak ketemu jawabannya.

Berdasarkan cuplikan wawancara pertanyaan nomor 3 untuk S6, terlihat bahwa S6 dapat memahami isi soal cerita dengan baik sehingga dapat menjelaskan mengenai alternatif penyelesaian penggunaan rumus serta pengetahuan yang digunakan dalam memecahkan masalah yang diberikan. Selanjutnya, jawaban tertulis pertanyaan nomor 3 dari S8 disajikan pada Gambar 12 dan cuplikan wawancara pertanyaan nomor 3 untuk S8 disajikan pada Tabel 13.

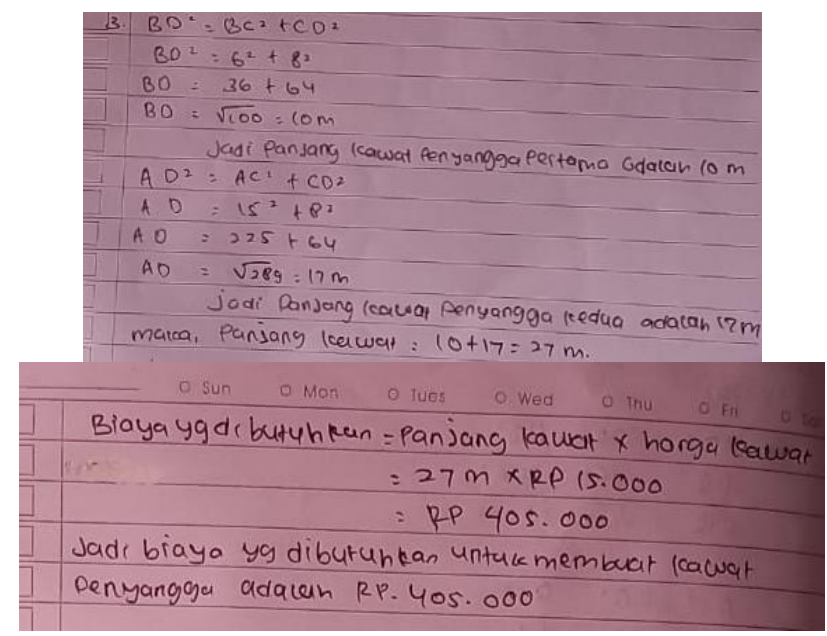

Gambar 12. Jawaban Pertanyaan Nomor 3 dari S8

Berdasarkan jawaban tertulis dari S8 pada Gambar 12, menunjukkan bahwa S8 dapat memunculkan alternatif penyelesaian menggunakan rumus-rumus yang telah diketahuinya serta pengetahuan yang digunakan dalam pemecahan masalah dengan sangat baik. Berdasarkan jawaban yang diberikan S8 pada Gambar 12, peneliti melakukan wawancara kepada S8.

Tabel 14. Cuplikan Wawancara Pertanyaan Nomor 3 untuk S8

\begin{tabular}{|c|l|}
\hline \multicolumn{1}{|c|}{ Subjek 8} \\
\hline P: & $\begin{array}{l}\text { Sekarang coba jelaskan apa saja yang diketahui, ditanyakan dan juga proses pengerjaan } \\
\text { untuk soal nomor 3! }\end{array}$ \\
\hline & $\begin{array}{l}\text { Nomor 3 yang ditanya panjang total kawat yang diperlukan dan biaya yang diperlukan jika } \\
\text { harga kawat 15.000 per meter. Nah cara nyelesaiinnya itu } \mathrm{BD}^{2}=\mathrm{BC}^{2}+\mathrm{CD}^{2}=6^{2}+8^{2}=36 \\
+64=100,100 \text { diakar kuadratkan sama dengan } 10, \text { jadi panjang kawat penyangga pertama } \\
\text { adalah 10 m. Kalo yang AD nya itu, } \mathrm{AD}^{2}=\mathrm{AC}^{2}+\mathrm{CD}^{2}=15^{2}+8^{2}=225+64=289,289 \\
\text { di akar kuadratkan sama dengan } 17, \mathrm{jadi} \text { panjang kawat penyangga kedua adalah 17 m. Jadi } \\
\text { panjangnya itu ditambahin 10 } \mathrm{m}+17 \mathrm{~m}=27 \mathrm{~m} . \text { Biaya yang dibutuhin adalah rumusnya } \\
\text { panjang kawatnya dikali harga kawat, jadi } 27 \mathrm{~m} \mathrm{x} 15.000=\mathrm{Rp} .405 .000 \text {. jadi hasil nomor } \\
\text { 3 adalah Rp. 405.000. }\end{array}$ \\
\hline P: & Menurut kamu bagian tersulit dalam soal ini apa? \\
\hline S8: & Nggak ada sih kak, kalo ada rumusnya jadi tinggal di masukin, tinggal cocokin aja. \\
\hline
\end{tabular}

Berdasarkan cuplikan wawancara pertanyaan nomor 3 untuk S8, terlihat bahwa S8 dapat memahami isi soal cerita dengan sangat baik sehingga dapat menjelaskan mengenai alternatif penyelesaian penggunaan rumus serta pengetahuan yang digunakan dalam memecahkan masalah yang diberikan. 
Identifikasi Pemecahan Masalah Matematis Peserta Didik Berdasarkan Tipe Kepribadian Hippocrates-Galenus dan Gender, Danu Yunizar Pamungkas, Rizki Dwi Siswanto

Pertanyaan nomor 4 tes kemampuan pemecahan masalah matematis mengenai indikator kemampuan merumuskan masalah situasi sehari-hari dalam matematika, sebagai berikut: "Sebuah kapal berlayar ke arah timur sejauh $200 \mathrm{~km}$, selanjutnya ke arah selatan sejauh $210 \mathrm{~km}$. hitunglah jarak kapal sekarang dari tempat semula!”. Jawaban tertulis pertanyaan nomor 4 dari S2 disajikan pada Gambar 13 dan cuplikan wawancara pertanyaan nomor 4 untuk S2 disajikan pada Tabel 14.

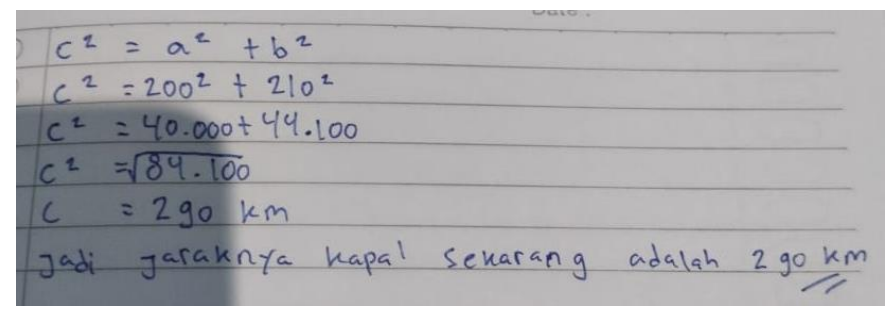

Gambar 13. Jawaban Pertanyaan Nomor 4 dari S2

Berdasarkan jawaban tertulis dari S2 pada Gambar 13, menunjukkan bahwa S2 dapat merumuskan masalah situasi sehari-hari ke dalam pembelajaran matematika dengan baik. Berdasarkan jawaban yang diberikan S2 pada Gambar 13, peneliti melakukan wawancara kepada S2.

Tabel 15. Cuplikan Wawancara Pertanyaan Nomor 4 untuk S2

\begin{tabular}{|c|l|}
\hline \multicolumn{2}{|c|}{ Subjek 2 } \\
\hline P: & $\begin{array}{l}\text { Sekarang coba jelaskan apa saja yang diketahui, ditanyakan dan juga proses pengerjaan } \\
\text { untuk soal nomor 4! }\end{array}$ \\
\hline S2: & $\begin{array}{l}\text { Yang nomor 4, jarak kapal sekarang adalah } \mathrm{C}^{2}=\mathrm{A}^{2}+\mathrm{B}^{2}=200^{2}+210^{2}=200 \mathrm{x} 200+210 \\
\text { x 210 = 40000 + 44100 = 84100, dan 84100 di akar kuadratin menjadi } 290 \mathrm{~km} .\end{array}$ \\
\hline P: & $\begin{array}{l}\text { Pernah gak sih kamu menemukan permasalahan pythagoras seperti ini di kehidupan sehari- } \\
\text { hari? }\end{array}$ \\
\hline S2: & Gak kak, aku gak pernah nemu. \\
\hline
\end{tabular}

Berdasarkan cuplikan wawancara pertanyaan nomor 4 untuk S2, terlihat bahwa S2 dapat merumuskan masalah situasi sehari-hari ke dalam pembelajaran matematika dengan cukup baik namun S2 tidak memiliki pengalaman atau tidak memahami mengenai konsep matematis berdasarkan pengetahuan dan pengalaman serupa yang ada pada kehidupan sehari-hari. Selanjutnya, jawaban tertulis pertanyaan nomor 4 dari S4 disajikan pada Gambar 14 dan cuplikan wawancara pertanyaan nomor 4 untuk S4 disajikan pada Tabel 15.

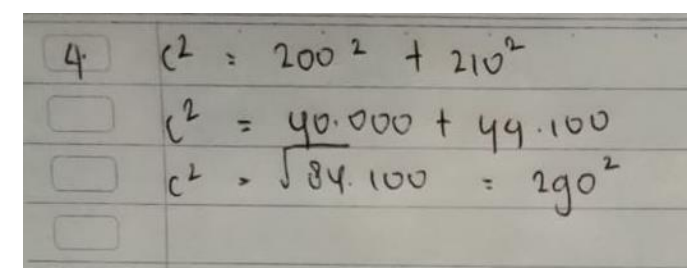

Gambar 14. Jawaban Pertanyaan Nomor 4 dari S4

Berdasarkan jawaban tertulis dari S4 pada Gambar 14, menunjukkan bahwa S4 dapat merumuskan masalah situasi sehari-hari ke dalam pembelajaran matematika dengan baik. Berdasarkan jawaban yang diberikan S4 pada Gambar 14, peneliti melakukan wawancara kepada S4. 
Tabel 16. Cuplikan Wawancara Pertanyaan Nomor 4 untuk S4

\begin{tabular}{|c|l|}
\hline P: & $\begin{array}{l}\text { Sekarang coba jelaskan apa saja yang diketahui, ditanyakan dan juga proses pengerjaan } \\
\text { nomor 4! }\end{array}$ \\
\hline S4: & $\begin{array}{l}\text { Sebuah kapal berlayar ke arah timur sejauh 200 km selanjutnya ke arah selatan sejauh 210 } \\
\text { km, yang ditanya adalah hitunglah jarak kapal dari tempat semula. Akar pangkat dari } 200 \\
\text { dan 210 ditambahkan lalu hasilnya 290. }\end{array}$ \\
\hline P: & $\begin{array}{l}\text { Pernah gak sih kamu menemukan permasalahan pythagoras seperti ini di kehidupan sehari- } \\
\text { hari? }\end{array}$ \\
\hline S4: & $\begin{array}{l}\text { Kalo untuk saat ini saya belum pernah ngelakuin dalam kehidupan sehari-hari tapi saya } \\
\text { pernah liat orang tua saya menghitung siku-siku pada tembok sama menentukan bidang } \\
\text { miring. }\end{array}$ \\
\hline
\end{tabular}

Berdasarkan cuplikan wawancara pertanyaan nomor 4 untuk S4, terlihat bahwa S4 dapat menjelaskan mengenai perumusan masalah situasi sehari-hari ke dalam pembelajaran matematika secara singkat, S4 juga dapat memahami mengenai konsep matematis berdasarkan pengetahuan dan pengalaman yang serupa pada kehidupan sehari-hari. Selanjutnya, jawaban tertulis pertanyaan nomor 4 dari S6 disajikan pada Gambar 15 dan cuplikan wawancara pertanyaan nomor 4 untuk S6 disajikan pada Tabel 16.

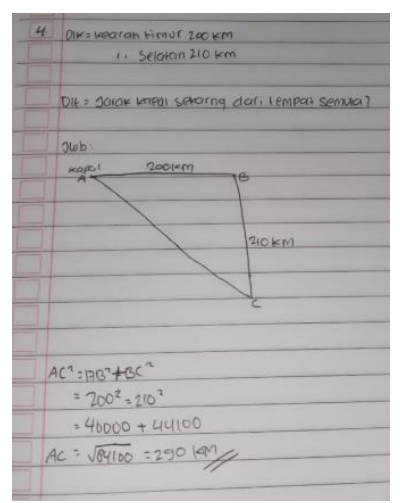

Gambar 15. Jawaban Pertanyaan Nomor 4 dari S6

Berdasarkan jawaban tertulis dari S6 pada Gambar 15, menunjukkan bahwa S6 dapat merumuskan masalah situasi sehari-hari ke dalam pembelajaran matematika dengan baik. Berdasarkan jawaban yang diberikan S6 pada Gambar 15, peneliti melakukan wawancara kepada S6.

Tabel 17. Cuplikan Wawancara Pertanyaan Nomor 4 untuk S6

\begin{tabular}{|c|l|}
\hline \multicolumn{2}{|c|}{ Subjek 6 } \\
\hline P: & $\begin{array}{l}\text { Sekarang coba jelaskan apa saja yang diketahui, ditanyakan dan juga proses pengerjaan untuk } \\
\text { soal nomor 4! }\end{array}$ \\
\hline S6: & $\begin{array}{l}\text { Diketahui nomor 4, kapal berlayar kearah timur sejauh 200 km dan kearah selatan sejauh } 210 \\
\text { km. }\end{array}$ \\
\hline P: & Pernah gak sih kamu menemukan permasalahan pythagoras seperti ini di kehidupan sehari-hari? \\
\hline S6: & $\begin{array}{l}\text { Saya pernah menemukan beberapa masalah di kehidupan sehari-hari seperti apa yang saya } \\
\text { kerjakan soal ini. }\end{array}$ \\
\hline
\end{tabular}

Berdasarkan cuplikan wawancara pertanyaan nomor 4 untuk S6, terlihat bahwa S6 tidak menjelaskan mengenai perumusan masalah situasi sehari-hari ke dalam pembelajaran matematika melainkan hanya 
Identifikasi Pemecahan Masalah Matematis Peserta Didik Berdasarkan Tipe Kepribadian Hippocrates-Galenus dan Gender,

menyebutkan apa yang diketahui saja, S6 memiliki pengalaman serupa atau memahami mengenai konsep matematis berdasarkan pengetahuan dan pengalaman yang serupa pada kehidupan sehari-hari.

Selanjutnya, jawaban tertulis pertanyaan nomor 4 dari S8 disajikan pada Gambar 16 dan cuplikan wawancara pertanyaan nomor 4 untuk S8 disajikan pada Tabel 17.

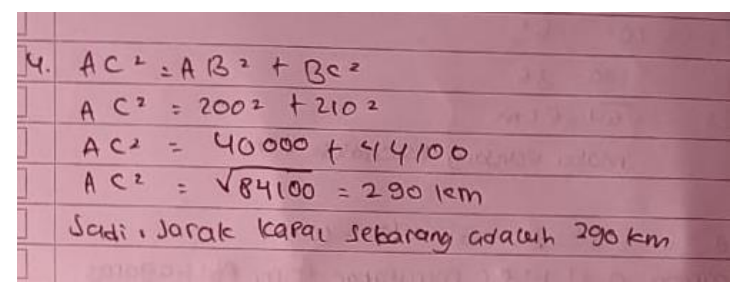

Gambar 16. Jawaban Pertanyaan Nomor 4 dari S8

Berdasarkan jawaban tertulis dari S8 pada Gambar 16, menunjukkan bahwa S8 dapat merumuskan masalah situasi sehari-hari ke dalam pembelajaran matematika dengan baik. Berdasarkan jawaban yang diberikan S8 pada Gambar 16, peneliti melakukan wawancara kepada S8.

Tabel 18. Cuplikan Wawancara Pertanyaan Nomor 4 untuk S8

\begin{tabular}{|c|l|}
\hline \multicolumn{1}{|c|}{ Subjek 8} \\
\hline P: & $\begin{array}{l}\text { Sekarang coba jelaskan apa saja yang diketahui, ditanyakan dan juga proses pengerjaan } \\
\text { untuk soal nomor 4! }\end{array}$ \\
\hline S8: & $\begin{array}{l}\text { Nomor 4 ditanya jarak kapal sekarang dari tempat semula. Nah cara nyelesaiinnya itu } \mathrm{AC}^{2} \\
=\mathrm{AB}^{2}+\mathrm{BC}^{2}=200^{2}+210^{2}=40000+44100=84100,84100 \text { di akar kuadrat jadi } 290 \mathrm{~km} .\end{array}$ \\
\hline $\mathrm{P}:$ & $\begin{array}{l}\text { Pernah gak sih kamu menemukan permasalahan pythagoras seperti ini di kehidupan sehari- } \\
\text { hari? }\end{array}$ \\
\hline S8: & $\begin{array}{l}\text { Pernah nemunya yang nomor 2 tentang kayak panjang gitu trus tentang harga-harga kayak } \\
\text { abis beli barang. }\end{array}$ \\
\hline
\end{tabular}

Berdasarkan cuplikan wawancara pertanyaan nomor 4 untuk S8, terlihat bahwa S8 dapat menjelaskan mengenai perumusan masalah situasi sehari-hari ke dalam pembelajaran matematika, S8 memiliki pengalaman serupa atau memahami mengenai konsep matematis berdasarkan pengetahuan dan pengalaman yang serupa pada kehidupan sehari-hari. Hasil deskripsi dari 8 subjek penelitian, memperlihatkan kemampuan pemecahan masalah matematis yang berbeda-beda pada setiap subjek dipengaruhi oleh tipe kepribadian dan gender peserta didik. Triangulasi data dari hasil tes kemampuan pemecahan masalah matematis dan wawancara menunjukkan hasil sebagai berikut.

\begin{tabular}{|c|c|c|c|c|c|c|}
\hline \multicolumn{7}{|c|}{ Tabel 19. Hasil Triangulasi Data } \\
\hline & & & \multicolumn{4}{|c|}{ Indikator Kemampuan Pemecahan Masalah Matematis } \\
\hline Subjek & $\begin{array}{c}\text { Tipe } \\
\text { Kepribadian }\end{array}$ & Gender & $\begin{array}{c}\text { Menunjukkan } \\
\text { Pemahaman } \\
\text { Masalah }\end{array}$ & $\begin{array}{c}\text { Mampu } \\
\text { membuat } \\
\text { atau } \\
\text { menyusun } \\
\text { model } \\
\text { matematika }\end{array}$ & $\begin{array}{c}\text { Memilih dan } \\
\text { mengembangkan } \\
\text { strategi } \\
\text { pemecahan } \\
\text { masalah }\end{array}$ & $\begin{array}{c}\text { Mampu } \\
\text { Menjelaskan dan } \\
\text { Memeriksa } \\
\text { Kebenaran } \\
\text { Jawaban yang } \\
\text { Diperoleh }\end{array}$ \\
\hline $\mathrm{S} 1$ & Sanguinis & Laki-laki & $\checkmark$ & $\checkmark$ & $\checkmark$ & $\checkmark$ \\
\hline $\mathrm{S} 2$ & Sanguinis & Perempuan & $x$ & $\checkmark$ & $\checkmark$ & $\checkmark$ \\
\hline S3 & Koleris & Laki-laki & $x$ & $x$ & $x$ & $\checkmark$ \\
\hline S4 & Koleris & Perempuan & $\checkmark$ & $\checkmark$ & $\checkmark$ & $x$ \\
\hline S5 & Melankolis & Laki-laki & $\checkmark$ & $x$ & $\checkmark$ & $\checkmark$ \\
\hline
\end{tabular}




\begin{tabular}{|c|c|c|c|c|c|c|}
\hline S6 & Melankolis & Perempuan & $\checkmark$ & $\checkmark$ & $\checkmark$ & $\mathbf{x}$ \\
\hline S7 & Plegmatis & Laki-laki & $\mathbf{x}$ & $\mathbf{x}$ & $\checkmark$ & $\checkmark$ \\
\hline S8 & Plegmatis & Perempuan & $\checkmark$ & $\checkmark$ & $\checkmark$ & $\checkmark$ \\
\hline
\end{tabular}

\section{KESIMPULAN}

Kesimpulan dari hasil penelitian dan analisis data di atas, pada tipe kepribadian sanguinis bergender laki-laki memenuhi semua aspek kemampuan pemecahan masalah matematis sedangkan untuk sanguinis bergender perempuan hanya aspek menunjukkan pemahaman masalah yang tidak terpenuhi, pada tipe kepribadian koleris bergender laki-laki hanya memenuhi aspek kemampuan menjelaskan dan memeriksa kebenaran jawaban yang diperoleh sedangkan untuk koleris bergender perempuan justru hanya aspek kemampuan menjelaskan dan memeriksa kebenaran jawaban yang diperoleh yang tidak terpenuhi, pada tipe kepribadian melankolis bergender laki-laki hanya aspek kemampuan membuat atau menyusun model matematika yang tidak terpenuhi sedangkan untuk melankolis bergender perempuan hanya aspek kemampuan menjelaskan dan memeriksa kebenaran jawaban yang diperoleh yang tidak terpenuhi, pada tipe kepribadian plegmatis bergender laki-laki terdapat 2 aspek yang tidak terpenuhi yaitu kemampuan menunjukkan pemahaman masalah dan kemampuan membuat atau menyusun model matematika sedangkan untuk plegmatis bergender perempuan memenuhi semua aspek kemampuan pemecahan masalah matematis.

\section{UCAPAN TERIMA KASIH}

Dengan selesainya penelitian ini, saya ucapkan terimakasih kepada dosen-dosen program studi Pendidikan Matematika Universitas Muhammadiyah Prof. DR. HAMKA, kepala sekolah dan guru-guru SMP Negeri 13 Depok, dan seluruh pihak yang telah membantu dalam pelaksanaan kegiatan ini, sehingga terlaksana dengan baik, dan lancar.

\section{REFERENSI}

Aliyah, I. M., Yuhana, Y., \& Anwar, C. A. H. F. S. (2019). Kemampuan Koneksi Matematis Siswa Ditinjau dari Kemampuan Awal dan Gender. Jurnal Didaktik Matematika, 6(2), 161-178. https://doi.org/10.24815/jdm.v6i2.14104

Amalia, S. R., \& Widodo, A. N. A. (2018). Analisis Kemampuan Pemecahan Masalah Mahasiswa Melalui Model Pbl Berbasis Etnomatematika Ditinjau Dari Kepribadian Topologi Hippocrates Dan Galenus Tipe Cholearis Dan Phlegmantis. AKSIOMA : Jurnal Matematika Dan Pendidikan Matematika, 9(1), 1. https://doi.org/10.26877/aks.v9i1.2467

Chomaria, N. (2014). Tes Kepribadian Remaja Muslim. Surakarta: Al-Qudwah Publishing.

Chotimah, N. H. (2014). Pengaruh Model Pembelajaran Generatif (MPG) Terhadap Kemampuan Pemecahan Masalah dan Disposisi Matematis Siswa di Kelas X pada SMA Negeri 8 Palembang. Skripsi. Universitas PGRI Palembang.

Dwi Putra, H., Fathia Thahiram, N., Ganiati, M., Nuryana, D., Studi, P., Matematika, P., Siliwangi, I., Jenderal, J. T., Cimahi, S., Kunci, K., Pemecahan, K., Matematis, M., \& Siswa, P. (2018). Kemampuan Pemecahan Masalah Matematis Siswa SMP pada Materi Bangun Ruang Development of Project- 
Identifikasi Pemecahan Masalah Matematis Peserta Didik Berdasarkan Tipe Kepribadian Hippocrates-Galenus dan Gender,

Based Blended Learning Model to Support Student Creativity in Designing Mathematics Learning in Elementary School. Jurnal Ilmiah Pendidikan Matematika), 6(2), 82-90. http://journal.unipma.ac.id/index.php/jipm

Hendriana, H., \& Sumarmo, U. (2014). Penilaian Pembelajaran Matematika. Bandung: Reflika Aditama. Islamiah, N., Purwaningsih, W. E., Akbar, P., \& Bernard, M. (2018). Analisis Hubungan Kemampuan Pemecahan Masalah Matematis dan Self Confidence Siswa SMP. Journal on Education, 1(1), 47-57. Littauer, F. (2011). Personality plus at work: How to work successfully with anyone. Revell.

Maryanto, N. R., \& Siswanto, R. D. (2021a). Analisis Kemampuan Berpikir Kreatif Matematis Ditinjau dari Gaya Kognitif dan Gender. ANARGYA: Jurnal Ilmiah Pendidikan Matematika, 4(1), 109-118.

Maryanto, N. R., \& Siswanto, R. D. (2021b). Analisis Kemampuan Berpikir Kritis Matematis Ditinjau Dari Gaya Kognitif Implusif Dan Reflektif. ANARGYA: Jurnal Ilmiah Pendidikan Matematika, 4(1), 109118. https://doi.org/10.21043/jpm.v2i1.6341

Meylina, S. (2019). Proses Berpikir Kritis Siswa dalam Pemecahan Masalah Matematika Berdasarkan Tipe Kepribadian Tipologi. 22(22), 523-530.

Ngilawajan, D. A. (2013). Proses berpikir siswa SMA dalam memecahkan masalah matematika materi turunan ditinjau dari gaya kognitif field independent dan field dependent. PEDAGOGIA: Jurnal Pendidikan, 2(1), 71-83.

Nuraeni, R., \& Luritawaty, I. P. (2016). Mengembangkan Kemampuan Komunikasi Matematik Siswa Melalui Strategi Think Talk Write. Jurnal Pendidikan Matematika STKIP Garut, 5(2), 101-112.

OECD. (2020). PISA 2018 Database. 1-64.

Septianawati, D. (2014). Efektivitas Penerapan Metode Diskusi dengan Pendekatan Matematika Realistik Ditinjau dari Tipe Kepribadian Siswa Kelas VIII SMP Negeri di Kabupaten Lampung Timur. Efektivitas Penerapan Metode Diskusi Dengan Pendekatan Matematika Realistik Ditinjau Dari Tipe Kepribadian Siswa Kelas VIII SMP Negeri Di Kabupaten Lampung Timur, 3(August), 55-64. http://dx.doi.org/10.1016/j.scitotenv.2014.10.007

Siswanto, R. D., Hilda, A. M., \& Azhar, E. (2019). Development Combinatorics Realistic Mathematics Education Application based on the Android Mobile. International Journal of Innovation, Creativity and Change, 5(6), 123-140.

Sugiyono, P. D. (2017). Metode Penelitian Pendidikan: Pendekatan Kuantitatif, Kualitatif, R\&D (Cetakan $\mathrm{Ke})$. Bandung: CV Alfabeta.

Winarni, E. S., \& H. (2015). Matematika untuk PGSD (Keempat ed.). Bandung: Remaja Rosdakarya. 